\title{
Pendampingan Redesign Kemasan dan Pencatatan Laporan Keuangan Bandeng Lelaki
}

\author{
Siska Ernawati Fatimah', ${ }^{1}$ Ida Rosnidah ${ }^{2}$,Siti Nur Hadiyati ${ }^{3}$ \\ 1,2,3Univesitas Swadaya Gunung Jati Cirebon \\ Email: 1SiskaFatimah12@gmail.com, 2idarosnidah2010@gmail.com, \\ 3sitinurhadiyati@gmail.com
}

\begin{abstract}
Abstrak
Gaya hidup modern yang mengakomodir makanan serba instan dalam tampilan menarik, sehingga pelaku umkm berlomba-lomba untuk melakukan inovasi produknya, termasuk salah satunya adalah olahan dari ikan bandeng, yaitu bandeng isi yang dilakukan oleh umkm Bandeng Lelaki, sebagai mitra dalam melakukan pengabdian masyarakat khususnya pendampingan yang berada di Kota Cirebon. Permasalahan yang dihadapi oleh umkm Bandeng Lelaki adalah kemasan masih dibuat secara sederhana, pelaku umkm belum sepenuhnya memanfaatkan teknologi digital sebagai sarana promosi produknya, pengelolaan keuangan belum tertib. Metode dalam kegiatan pengabdian ini menggunakan observasi secara langsung pada lokasi UMKM Bandeng Lelaki. Selanjutnya kegiatan melakukan pertemuan dalam bentuk sosialisasi dan pendampingan. Hasil dari kegiatan pendampingan yang telah dilakukan kepada pelaku UMKM Bandeng Lelaki adalah sebagai berikut: pelaku usaha mampu mengidentifikasi bahan baku untuk kemasan sesuai kebutuhan, pelaku umkm mampu meciptakan ide desain kemasan dengan warna yang menarik, mampu membuat laporan keuangan secara mandiri, mampu membuat promosi digital melalui instagram untuk produknya menjadi lebih menarik.
\end{abstract}

Kata Kunci: redesign kemasan, pencatatan laporan keuangan

\begin{abstract}
Modern lifestyle that accommodates instant food in an attractive look, so that umkm actors are vying to innovate their products, including one of which is processed from fish bandeng, namely bandeng content done by umkm Bandeng Pria, as a partner in doing community service, especially mentoring in the city of Cirebon. The problem faced by umkm Bandeng Pria is that packaging is still made simply, msmes have not fully utilized digital technology as a means of promoting their products, financial management has not been orderly. The method in this devotional activity uses direct observation at the location of UMKM Bandeng Pria. Furthermore, the activity conducts meetings in the form of socialization and mentoring. The results of the mentoring activities that have been done to UMKM Bandeng Pria actors are as follows: businesses are able to identify raw materials for packaging as needed, umkm actors are able to create packaging design ideas with attractive colors, able to make financial statements independently, able to make digital promotions through instagram for their products to be more attractive.
\end{abstract}

Keywords : packaging redesign, recording of financial statements 


\section{Pendahuluan}

Wilayah pesisir memiliki potensi ekonomi strategis terutam bagi penduduknya. Potensi ekonomi ini dapat terlihat dari berbagai bentuk pemanfaatan sumberdaya seperti untuk usaha budidaya dan penangkapan ikan, pertanian, perindustrian, pemukiman, pelabuhan, pariwisata, dan pertambangan (Sukmana, 2020). Pemanfaatan sumberdaya pesisir untuk aktivitas pengolahan ikan memiliki potensi yang bagus ditinjau dari segi kuantitas maupun keanekaragamannya. Seiring dengan terus meningkatnya jumlah penduduk, permintaan akan hasil perikanan dengan kandungan protein yang tinggi juga semakin meningkat. Keadaan tersebut salah satunya ditandai dengan permintaan ikan bandeng yang secara nasional meningkat 6,33\% per tahun (Sudiyono, 2020).

Pemanfaatan sumber daya pesisir salah satunya adalah pemanfaatan ikan bandeng yang dapat memberikan dampak ekonomi terhadap masyarakat lokal(Adi Patra, 2017). Bandeng merupakan ikan yang disuka semua kalangan masyarakat, tetapi ikan tersbut memiliki kekurangan yaitu jumlah duri yang banyak, sehingga untuk mengkonsumsinya mengalami kesulitan (Winangsih, Widyastuti, \& Widyastuti, 2019). Disamping itu keterbatasan masyarakat dalam mengelola hasil panen ikan bandeng dan kompetisi dari daerah lain penghasil ikan bandeng menjadikan harga jual ikan bandeng cenderung tidak stabil dan jatuh. Oleh karena itu, perlu dilakukan suatu upaya pengendalian harga jual ikan bandeng (Jamaludin, Harahap, \& Afri, 2020). Salah satu upaya yang dapat digunakan adalah dengan melakukan pengolahan lebih lanjut pada ikan bandeng untuk meningkatkan nilai jual ikan bandeng serta untuk memberikan kemudahan dalam mengkonsumsi ikan bandeng (Ufafa 2020).

Berbagai pengolahan ikan bandeng agar mudah dimakan banyak dilakukan oleh para pelaku usaha dengan menjadikan ikan bandeng menjadi beberapa olahan yang menarik (Hadiratul Kudsiah, Joeharnani Tresnati, 2018). Hal ini juga dilakukan oleh UMKM Bandeng Lelaki dengan mengolah ikan bandeng menjadi bandeng tanpa isi dengan berbagai varian isi seperti original, pedas, ayam sapi, mozarella, mayanaise, sambel goreng pete, jengkol balado, dan bakar. Permasalahan yang dihadapi oleh umkm Bandeng Lelaki adalah kemasan masih dibuat secara sederhana, pengelolaan keuangan masih mengandalkan daya ingat pemilik, pelaku umkm belum optimal dalam memanfaatkan teknologi digital sebagai sarana promosi produknya.

Berdasarkan masalah tersebut maka solusi yang ditawarkan untuk menangani permasalahan yang dialami oleh mitra adalah kegiatan pendampingan yang dibutuhkan oleh mitra adalah yang pertama melakukan redesign kemasan sehingga dapat bersaing dipasar. Desain kemasan merupakan salah satu faktor penting dalam penjualan produk. Desain kemasan yang baik tidak hanya menarik bila dipajang di rak penjualan, tetapi juga dapat meyakinkan konsumen untuk membeli (Kustini, Yuniningsih, \& Winarti, 2019) dan bersedia membayar untuk produk dilihatnya (Sri Winarti, 2020).

Berbagai usaha dilakukan dalam upaya memenangkan persaingan. Salah satu diantaranya adalah membuat desain kemasan produk yang menarik sehingga dapat 
mengundang konsumen untuk membeli produk. Menurut Kington, Chapman, Clarke, \& Beesley, (2018) berpendapat bahwa desain merupakan totalitas keistimewaan yang mempengaruhi penampilan dan fungsi suatu produk dari segi kebutuhan konsumen. Desain produk dapat meningkatkan kualitas dan keawetan produk, selain itu juga dapat menambah daya penampilan produk. Desain kemasan produk juga digunakan untuk merangsang konsumen sacara emosional ketika menggunakan produk. Oleh karena itu desain kemasan harus dirancang sesuai dengan target calon konsumen yang diharapkan.


Gambar 1. Kemasan Bandeng Lelaki Saat Ini

Kebutuhan mitra yang kedua adalah bagaimana memanfaatkan teknologi digital sebagai sarana promosi produknya. Promosi juga merupakan bagian penting dalam pemasaran selain mengembangkan produk yang baik, menetapkan harga yang atraktif dan menyediakan produk tersebut bagi pelanggan. Menurut Amstrong, (2018) promosi merupakan sebuah sarana untuk mengkomunikasikan nilai kepada pelanggan dengan menggunakan media. Berbagai macam media promosi yang dapat digunakan dengan memanfaatkan teknologi, yang sekarang ini pemanfaatan media promosi dengan menggunakan media sosial, yang dinilai efektif dalam membidik konsumen. Media Sosial Menurut Kotler, Armstrong, Harris, \& He, (2020) adalah merupakan suatu media bagi konsumen untuk menerima berbagai informasi berupa teks, gambar, video, maupun audio, antara satu sama lain dan atau antara perusahaan begitupun sebaliknya. Berbagai macam bentuk media sosial namum yang paling populer sebagai media marketing adalah Instagram. Instagram merupakan suatu aplikasi di dalamnya dapat melakukan aktivitas photo-sharing, video dengan durasi 15 detik, selain itu juga digunakan sebagai media laternatif baru dalam melancarkan promosi penjualan untuk menyampaikan pesan dari suatu brand.

Kebutuhan mitra yang ketiga adalah pengelolaan keuangan yang belum teratur. Masih banyak ditemukan UMKM yang belum paham akan fundamentalnya peran laporan keuangan. Laporan keuangan pada UMKM Bandeng Lelaki hanya dibuat seadanya, ditulis manual dengan format seadanya, dan tidak menggunakan standar prinsip akuntansi yang tepat, akibatnya seringkali terdapat kekeliruan dalam penarikan kesimpulan terhadap laba/rugi karena tidak tertibnya pelaporan keuangan 
usaha. Laporan keuangan UMKM berdasarkan standar akuntnasi menggunakan SAK EMKM (Standar Akuntansi Keuangan Entitas Mikro Kecil dan Menengah), selain itu juga diperkuat dengan undang-undangan No 20 tahun 2008, UMKM dibedakan sesuai kriteria masing-masing meliputi usaha mikro, usaha kecil dan usaha kecil menengah. Sehingga laporan keuangan bagi umkm sangatlah penting guna menunjang keberlangsungan hidup umkm.

Kegiatan pengabdian masyarakat ini bertujuan untuk memberikan pengetahuan kepada pelaku usaha Bandeng Lelaki mengenai kegiatan pemasaran yang meliputi redesign kemasan dan penggunaan media sosial instagram untuk sarana promosi serta membuat laporan keuangan sederhana. Manfaat dari kegiatan pengabdian ini diharapkan dapat membuat produk UMKM Bandeng Lelaki dapat mengalami peningkatan penjualan sehinggan dapat diketahui oleh masyarakat luas serta UMKM Bandeng Lelaki dapat memehami pembuatan laporan keuangan sederhana.

\section{Metode}

Motode kegiatan pengabdian ini dengan memberikan pendampingan kepada umkm Bandeng Lelaki. Prosedur kerja kegiatan pengabdian masyarakat dimulai dengan seleksi proposal oleh Lembaga Pengabdian Masyarakat UGJ, kemudian menyiapkan bahan materi yang akan disampaikan kepada pelaku usaha, setelah itu pelaksanaan kegiatan pengabdian masyarakat melibatkan pemilik usaha dan karaywan pada umkm Bandeng Lelaki. Kegiatan pengabdian ini mulai dari observasi sampai dengan pelaksanaan pendampingan dilakukan dalam waktu satu bulan dengan melibatkan mahasiswa sebagai enumerator guna meningkatkan rasa kepedulian terhadap permasalahan yang terjadi di usaha masyarakat.

Kegiatan yang dilaksanakan dalam pengabdian masyarakat ini meliputi:

1. Observasi

Kegiatan observasi diawali dengan berkomunikasi melalui telepon dengan pemilik umkm Bandeng Lelaki pada awal bulan September 2020, kemudian dilanjutkan dengan observasi langsung ke tempat umkm Bandeng Lelaki pada bulan Oktober 2020. Dari observasi tersebut, memperoleh informasi tentang kendala yang dihadapi kemasan masih dalam bentuk sederhana, belum optimal memanfaatkan teknologi untuk promosi penjualan, dan belum adanya laporan keuangan.

2. Pendampingan

Kegiatan pendampingan dilakukan pada bulan Januari 2021, bertempat di UMKM Bandeng Lelaki Kecamatan Kesambi Kota Cirebon. Metode pendampingan yang digunakan adalah pendampingan langsung pada tiap pemilik dan karyawan Bandeng Lelaki. Metode ini dinilai lebih efektif dan hasilnya sesuai dengan harapan. Pendampingan dilakukan secara langsung dengan mengunakan protokol kesehatan yaitu menggunakan masker dan jaga jarak. Pemilik dan karyawan diberikan pengarahan tentang peermasalahan yang dihadapi dan diteruskan 
dengan berdiskusi bersama untuk mendapatkan solusi dari permasalahan yang ada.

\section{Hasil dan Pembahasan}

Kegiatan Pendampingan pada Pengabdian Kepada Masyarakat ini diawali dengan pengenalan dan pemahaman pentingnya kegiatan pemasaran khususnya kemasan dan penyusuanan laporan keuangan secara sederhana dimana strategi ini digunakan untuk menunjang keberlangsungan hidup usaha. Pelaksanaan kegiatan meliputi pendampingan langsung dilanjutkan dengan diskusi dengan pemilik dan karyawan UMKM Bandeng Lelaki. Adapun kegiatan yang dilakukan terbagi menjadi beberapa tahapan yaitu:

Tabel 1. Tahapan Kegiatan

\begin{tabular}{|c|l|c|}
\hline No & \multicolumn{1}{|c|}{ Nama Kegiatan } & Waktu Pelaksanaan \\
\hline 1 & $\begin{array}{l}\text { Sosialisasi program yang akan } \\
\text { dilaksankan }\end{array}$ & 2 jam \\
\hline 2 & $\begin{array}{l}\text { Membuat materi yang akan } \\
\text { disampaikan ke pelaku umkm }\end{array}$ & 4 hari \\
\hline 3 & Pendampingan Redesign Kemasan & 4 jam sehari selama 2 hari \\
\hline 4 & Pendampingan optimalisasi instagram & 3-4 jam perhari selama 3 hari \\
\hline 5 & $\begin{array}{l}\text { Pendampingan pemahaman dan } \\
\text { pembuatan laporan keuangan }\end{array}$ & 4 jam \\
\hline 6 & Evaluasi Program Kegiatan & $\begin{array}{c}\text { Selama waktu pengabdian } \\
\text { masyarakat }\end{array}$ \\
\hline 7 & Pembuatan dan penyusunan Laporan \\
\hline
\end{tabular}

Kegiatan sosialisasi yaitu dengan memberikan informasi dan penjelasan mengenai kegiatan yang akan dilakukan oleh tim kegiaatan, manfaat pemasaran dan akuntansi yang akan diterima oleh umkm Bandeng Lelaki dan kesepakatan pelaksanaan jadwal kegiatan pengabdian. Kegiatan ini dilakukan dengan melakukan kunjungan ke tempat mitra selama kurang lebih 3 jam dengan melakukan diskusi mengenai kegiatan yang akan dikerjakan selama pengabdian.

Pada tahapan pembuatan materi dilakukan selama 4 hari diawali dengan melakukan pembahasan secara bersama teman-teman satu tim kemudian kemudian menentukan materi yang akan disampaikan kepada mitra. Materi yang akan disampaikan mulai dari menentukan bagaimana bentuk kemasan yang akan diberikan kepada mitra, mimilih bahan kemasan yang sesuai dengan produk, memilih media sosial yang akan digunakan disesuaikan dengan keadaan mitra kemudian untuk aplikasi dimulai dari pendaftaran sampai dengan bagaimana mengoptimalkan penggunaan, menyusun bentuk laporan keuangan sederhana yang akan digunakan oleh mitra. 
Pada tahap pendampingan kegiatan pemasaran yang dilakukan oleh tim pelaksana kepada mitra dengan memberikan informasi mengenai pendampingan, tentang kegiatan pemasaran yang fokus untuk meredesign kemasan yang sudah ada menjadi lebih menarik. Dalam kegiatan didapat informasi bahwa selama ini UMKM Bandeng Lelaki menggunakan kemasan plastik yang di sablon hal ini dilakukan agar biaya produksi tidak terlalu mahal, namun di peroleh fakta bahwa dengan kemasan tersebut UMKM Bandeng Lelaki sulit untuk melakukan strategi penjualan untuk roduk yang sejenis karena kemasannya lebih menarik. Selanjutnay tim memberikan kemasan yang baru utuk UMKM Bnadeng Lelaki sebanyak 500 kemasan yang siap digunakan untuk produk Bandeng Lelaki. Kegiatan ini berlangsung selama dua jam.

Pada tahap kegiatan pendampingan media sosial yang digunakan untuk pemasaran, tim pelaksana melakukan pendampingan menggunakan pemasaran Instagram. Instagram dipilih sebagai media promosi dikarenakan banyak pengusaha atau pemilik usaha melakukan promosi menggunakan instagram karena mendapat respon yang cukup baik oleh konsumen. Waktu pelaksanaan kegiatan ini selama 3 jam, dimana mitra sangat antusias melakukan kegiatan tersebut, mitra merasa sangat terbantu dengan diberikannya pendampingan instargaram sebagai media promosi penjualan oleh tim pengabdian. Dengan harapan produk yang dijual mengalami peningkatan penjualan dan produk dapat dikenal oleh masyarakat diluar kota cirebon.

Tahapan evaluasi merupakan kegiatan untuk melihat bagaimana kemampuan mitra setelah dilakukan pendampingan dari tim pelaksana. Dengan melakukan pendampingan selama satu bulan dapat dilihat hasilnya yaitu menghasilkan kemasan yang baru yang lebih menarik, mampu mengoptimalkan media sosial sebagai sarana pemasaran yaitu instragram yang dapat dimanfaatkan oleh mitra, mampu membuat laporan keuangan sederhana yang sistematis. Evaluasi selanjutkan akan dilakukan dengan melihat perkembangan penjualan mitra.

Pada kegiatan akhir dalam pengabdian masyarakat ini adalah membuat laporan pengabdian sebagai bukti pertanggungjawaban tim pelaksana kegiatan.

Adapun hasil dari kegiatan pengabdian masyarakat sebagai berikut.

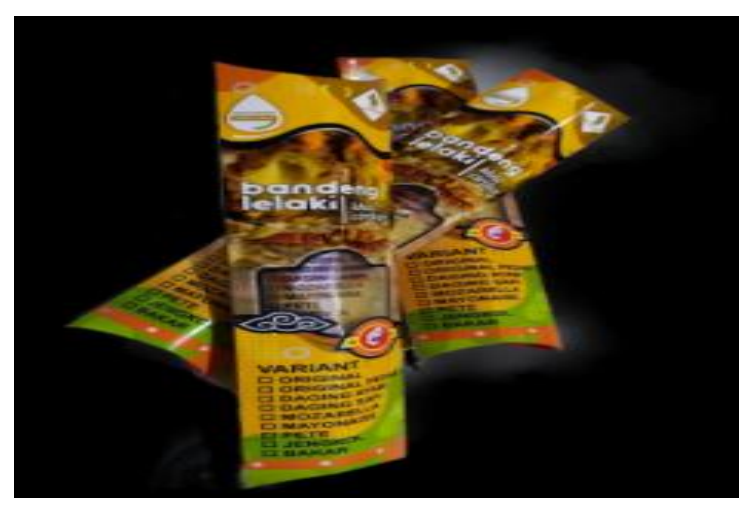

Gambar 2. Redesign Kemasan 
Gambar 2 merupakan hasil kemasan redesign kemasaan yang telah dihasilkan menggunakan desain produk dengan pemilihan warna yang lebih menarik

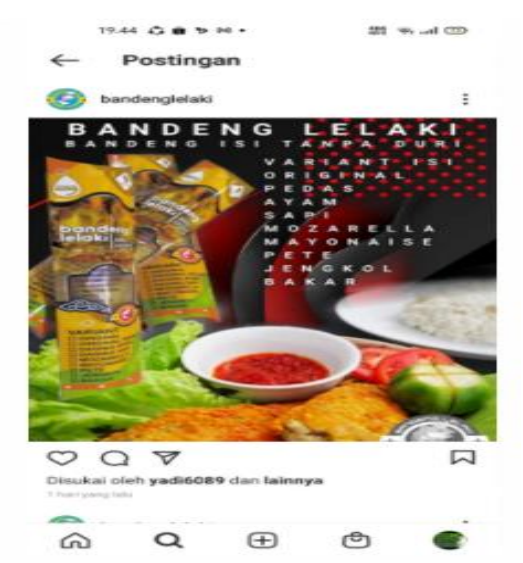

Gambar 3. Pendampingan Instagram

Gambar 3 merupakan hasil pendampingan menggunakan instagram untuk melakukan promosi penjualannya

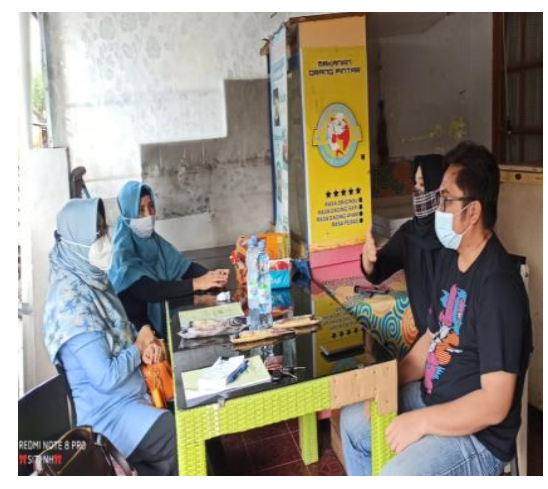

Gambar 4. Pendampingan Penyusuanan Laporan Keuangan

Gambar 4 merupakan hasil pendampingan penyusunan laporan keuangan secara sistematis dimana mitra mulai memahami apa saja yang harus dimasukan ke dalam laporan keuangan.

Berdasarkan kegiatan pendampingan dan diskusi dengan pemilik dan karyawan UMKM Bandeng Lelaki pada kegiatan pengabdian masyarakat diperoleh informasi sebagai berikut

1. Kemasan produk yang dijual sudah cukup menarik namun masih sangat sederhana dari segi bentuk dan warna dan belum lengkap informasinya dalam kemasan. Agar produk mudah dikenal diarahkan untuk mempunyai ciri kemasan baik dari segi bentuk maupun warna. Selanjutnya kemasan produk tersebut didiskusikan, dimulai dari pemilihan bahan baku untuk kemasan, bentuk kemasan, tulisan yang akan dicantumkan dalam kemasan, sampai dengan warna 
yang akan digunakan dalam kemasan tersebut. Kemasan yang sudah di redesign oleh kami akan diimplementasikan oleh pelaku UMKM Bandeng Lelaki.

2. Metode pemasaran yang dilakukan masih menggunakan word of mouth dan menawarkan langsung ke konsumen, sehingga pelmilik dan karyawan UMKM Bandeng Lelaki pada saat pendampingan pemasaran menggunakan media instagram sangat antusias. Pemilik UMKM Bandeng Lelaki mengharapkan adanya pendampingan lanjutan mengenai pemanfaatan teknologi sehingga dapat melakukan penjualan secara online.

3. Kesulitan pelaku UMKM dalam mengelola laporan keuangan adalah pelaku belum memahami mana yang menjadi aset, modal maupun hutang. Pelaku UMKM mengelola keuangan berdasarkan daya ingat dan perkiraan pemilik, karena yang penting usahanya bisa berjalan, hal itu disebabkan karena pengetahuan mengenai laporan keuangan yang minim . Pelaku UMKM diharapkan memahami informasi akuntansi dan mulai melakukan pencatatan laporan keuangan sederhana minimal arus kas setelah mendapat pengetahuan pada saat dilakukan pendampingan oleh tim.

4. Bersarkan hasil diskusi dengan pemilik UMKM Bnadeng Lelaki, tim pengabdian dosen selanjutnya diharapkan menyelenggarakan kegiatan bagi para pelaku UMKM di kota Cirebon dengan mengenai pemanfaatan teknologi sebagai saran penjualan online dan kemampuan pelaku UMKM dalam mengelola keuangan.

\section{Simpulan dan Rekomendasi}

Kesimpulan kegiatan pengabdian ini berjalan lancar sampai dengan selesai dan mitra sangat antusias dalam mengikuti kegiatan pengabdian ini dengan melakukan diskusi bersama dan memilih design kemasan untuk bandeng lelaki yang baru dan menyusun laporan keuangan menjadi lebih sistematis. Kegiatan pengabdian ini telah menghasilkan redesign kemasan bandeng lelaki yang baru dan penggunaan media sosial instagram untuk pemasaran produknya serta membuat laporan keuangan secara sistematis.

Saran yang dapat diambil dalam kegiatan pendampingan ini berdasarkan hasil diskusi bahwa pelaku umkm perlu berperan aktif dalam membangun jaringan dalam komunitas kewirausahan yang diselenggarakan oleh dinas koperasi dan umkm Kota Cirebon. Pelaksana pendampingan perlu adanya pemantauan perkembangan usaha dan promosi digital agar dapat mengevaluasi kembali keberhasilan pendampingan ini. Penyelenggara pengabdian khususnya pendampingan perlu adanya pendampingan pada umkm mengenai penggunaan teknologi digital baik dalam segi promosi maupun penjualannya.

\section{Daftar Pustaka}

Adi Patra, A. D. (2017). Pengolahan Ikan Bandeng (Chanos-Chanos) Cabut Duri. RESONA : Jurnal Ilmiah Pengabdian Masyarakat. 
https://doi.org/10.35906/jipm01.v1i1.244

Amstrong, K. (2018). Princeples of Marketing.

Hadiratul Kudsiah, Joeharnani Tresnati, S. A. A. (2018). IbM Kelompok Usaha Bandeng Segar Tanpa Duri di Kabupaten Pangkep Sulawesi Selatan . Jurnal Panrita Abdi, 2(1), 55-63.

Jamaludin, Harahap, M. K., \& Afri, E. (2020). Penggunaan Albanto ( Alat Bandeng Presto ) untuk Meningkatkan Nilai Olahan Ikan Bandeng Desa Batang Kilat Medan. TRIDARMA: Pengabdian Kepada Masyarakat (PkM), 3(1), 136-142.

Kington, H., Chapman, M., Clarke, C., \& Beesley, S. (2018). Principles of marketing. In BSAVA Manual of Small Animal Practice Management and Development. https://doi.org/10.22233/9781910443156.25

Kotler, P., Armstrong, G., Harris, L. C., \& He, H. (2020). Principles of Marketing.

Kustini, K., Yuniningsih, Y., \& Winarti, S. (2019). Pelatihan Pemanfaatan Limbah Duri Bandeng Sebagai Bahan Pembuatan Krupuk Stik Di Kelurahan Gunung Anyar Tambak Kecamatan Rungkut Surabaya. Peduli, 2(2), 56-65.

Sri Winarti, Y. N. (2020). Pelatihan Pengemasan Dan Pelabelan Bandeng Sapit. 4(1).

Sudiyono, S. (2020). StudiI Tentang Bandeng Presto Crispy Pada. 3, 18-24.

Sukmana, N. C. (2020). Pelatihan dan penyuluhan pemanfaatan potensi ikan bandeng desa gumeno kabupaten gresik sebagai produk bernilai abon ikan bandeng. 5(2), 65-70.

Winangsih, R., Widyastuti, N. W., \& Widyastuti, Y. (2019). Membangun Kemandirian Pangan Melalui Manajemen Komunikasi Pemasaran Sate Bandeng Sebagai Produk Unggulan Kota Serang. Jurnal Pengabdian Masyarakat IPTEKS, 5(1), 105. https://doi.org/10.32528/pengabdian_iptek.v5i1.2268 